\title{
The Pitfalls of Sustainability Policies: Insights into Plural Sustainabilities
}

\author{
François Mancebo \\ International Research Center on Sustainability, Reims University, 57 bis, rue Pierre Taittinger, 51096 Reims \\ Cedex, France; E-Mail: francois.mancebo@univ-reims.fr; Tel.: +33612537446
}

Submitted: 21 December 2012 | In revised form: 30 March 2013 | Accepted: 24 May 2013 |

Published: 18 June 2013

\begin{abstract}
A lot can be learned from the numerous pitfalls of sustainable development implementation: they outline how collective representation, short term interests and balance of power can undermine sustainability. For instance, the usefulness of global institutions in dealing with sustainable development is questionable as most are skewed toward the interests and perceptions of developed countries. The notion of sustainable development itself induces a profound cleavage between academic authors and the actors of its implementation, some of whom confuse it with sustainable growth (which favors spatial equity), whilst the others with environment management (which favors intergenerational equity). This polarization is a real problem, since originally, "Our Common Future" report promotes an inclusive approach, able to cope with both equities simultaneously. Finally, if there are obligations toward future generations, there are also obligations toward the current generation. The key issue for effective sustainability policies should be making them acceptable to everyone by including the expectations of local societies and communities. As a matter of consequence, universal solutions do not exist. They would not meet the specificities of local circumstances. The traditional prescriptive sustainable development model should give way to flexible plural sustainabilities. Singular, top-down, global-to-local approaches to sustainable development should be substituted for multiple sustainabilities.
\end{abstract}

Keywords: actors strategies; environmental policies; planning; sustainability

\section{Introduction}

Throughout the 1990s, starting with the release of the World Commission on Environment and Development report [1], and even more so following the Rio
Summit, sustainable development began being widely discussed among international organizations such as the OECD, the European Union, and the WTO, as well as various NGOs. Rio's Agenda 21 has seen national and even regional and local governments enter into

(C) 2013 by the authors; licensee Librello, Switzerland. This open access article was published under a Creative Commons Attribution License (http://creativecommons.org/licenses/by/3.0/).

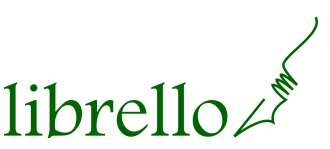


discussions on sustainability [2]. But with the ever increasing debates on sustainable development, the term took on a multiplicity of sometimes contradictory meanings [3]. It became an all-purpose grab bag of notions such as "development that is tolerable to ecosystems", "development that spares natural resources", "development that is conducive to a good quality of life", "that permits economic growth", "that drives employment opportunities", "that encourages social cohesion", and so forth. The situation is now so complex that it needs mapping [4]. This is all but natural as it is impossible to answer the basic question of what is sustainable and what is not because sustainable development is not only about science, but also about values [5], which means that various views and interpretations are likely to thrive since values may differ considerably between cultures and over time [6].

However, the core idea of sustainable development is simple enough: recognizing the finite nature of our biophysical environment. It promotes a type of development that meets the current needs of our societies without compromising those of future generations. Such a definition, however, points out three difficulties which are developed in this paper:

- $\quad$ The assumption that large and small scales of action can be treated similarly is all but evident (for example the nesting of local agenda $21 s$ within Agenda 21). Some environmental constraints that can seem absolute at the global level, often perceived as a matter of survival, appear merely insignificant at local or regional levels.

- Frequently sustainable development is confused with sustainable growth which, moreover, can be considered an oxymoron. The result is a contradiction between the imperative of a slowdown in the use of resources on the one hand and the willingness to ensure steady economic growth on the other. All the more so, since this contradiction creates an ever-larger gap between rich countries, which favor the environment and intergenerational equity, and poor countries, which favor economic growth for the sake of spatial equity.

- $\quad$ According to the "Our common future" report, if there are obligations toward future generations, there are also obligations toward current generations. All the more so, since predicting what kind of resources these future generations will require is a matter of speculation.

Besides, these three difficulties outline how collective representations, perceptions, short term interests and the balance of power between public actors may undermine the success of sustainable development policies-I shall call them sustainability policies-promoted by local societies and communities.
In this article, I will use the term sustainability as a synonym for sustainable development. Some authors consider sustainability to refer to objectives to be achieved, with sustainable development referring to the processes to achieve them [7]. Others interpret sustainable development as focusing on ameliorating economic growth by taking into account the environment, while sustainability focuses on the ability of humanity to live within the environmental limits of the planet [8]. Strictly speaking the distinction between sustainability and sustainable development is logical, otherwise the word development would be entirely useless, but at the same time it "needlessly complicates the sustainable development debate and merely shifts the complex and vibrant interpretational debate to the conceptual level" [9]. I agree with this idea since the debate on the difference between sustainable development and sustainability remains unresolved [10]. Leaving this issue open may create a "constructive ambiguity" [3].

\section{Linking the Different Spatial and Temporal Scales: A New Catch-22}

One major issue when trying to implement sustainability is the relevant scope to effective policies [11]. This issue becomes a bottleneck when considering, for example, cross-border pollution [12]. Cross-border pollution is classically connected with global phenomena such as greenhouse gases, or gases that impact the stratospheric ozone layer. However, it is a widespread problem with sources which can be precisely located. I will mention here three very different cases. In 2005, the explosion of a chemical plant in north-east China spilled huge amounts of benzene-a carcinogenic substance-into the Songhua River, which provides drinking water to millions of people in China and Russia [13]. Russian cities downstream had to cut their water supplies, affecting millions of people for several weeks. This ended in a long legal dispute between Russia and China over responsibilities and compensation [14]. This contamination can also be chronic: Japan is under constant threat from acid rain caused by the sulfur injected in the atmosphere by China's Shanxi province industrial plants and carried across the Sea of Japan by the wind [15]. In particularly great danger are the famous ice trees (juhyo) along with the fragile ecosystem that supports them on Mount Zao [16]. Sometimes cross-borders pollution ends in everlasting conflicts without solution. So is the contamination of the Rhine river by the French mining company Société des Mines de Potasse d'Alsace (MDPA), which resulted in a long-running environmental dispute [17]. The Netherlands accused the French company of dumping salt effluents (sulfates, ammonia, chlorides) into the Rhine. This pollution made the Rhine water unfit for agricultural purposes in addition to corroding water 
delivery systems. Despite a 1989 order by the Strasbourg Administrative Court in favor of the Dutch government, things continued largely unchanged until the MDPA site was closed by injunction of the court in 2004 [18].

The three cases show how difficult it is to delimit relevant areas for sustainability policies-the functional space of an industrial site, including its employment base, does not usually coincide with the area affected by the atmospheric or hydrographic pollution that it generates, and it often does not coincide with the territorial jurisdiction of the institution charged with regulating such issues, notwithstanding all the discussion about linking scales of action. Indeed, the assumption that large and small spatial scales can be easily drawn up raises a number of questions. Can the principles of sustainability $[19,20]$ really be applied identically from the global down to the local level, as if each level were controlling the other in some sort of gigantic planetary mechanism?

It is true that some global issues like climate change or ozone depletion need global answers embodied by top-down policies which should be translated directly into regional policies [21]. Johan Rockström identified a set of such critical sustainability issues where perturbations resulting from human activities present a risk of unacceptable global environmental change [22]. But even in these cases, if the top-down initiatives prove unenforceable because they have not been adjusted to accommodate local or regional considerations, they will be useless in addressing these problems, as with the mechanisms to reduce carbon emissions from deforestation and forest degradation (REDD) [23].

Thus, it would be an error to apply policies locally that do not fit the concerned areas, as would it be to dictate a single approach in defining problems and drafting solutions. In France, the utilization of sewage sludge on agricultural fields illustrates how not taking local concerns into account-here, perceptions of sewage sludge as a nuisance-can lead to major problems. While working on the periurbanization dynamic in the Ile-de-France (Paris metropolitan region), I realized that land application of sewage sludge often resulted in significant neighborhood conflicts addressing the quality of life at the local scale when this practice was considered sustainable at the regional scale [24]. These conflicts combined with distrust in industrial agriculture after the BSE (Bovine Spongiform Encephalopathy) crisis in the 1990s to provoke a persistent and massive rejection by the population (either neighbors or customers) of the land application of sludge (appendix). As mentioned by Flor Avelino, attempting to change human perceptions and behavior through imposed technocratic approaches usually leads to unsustainable power relations and conflicts [25]. However, it is important to remember that for more than a century Parisian sewage sludge was used to grow vegetables for the capital, and that traditional family gardens have always put human manure to good use. If sewage sludge has no health risks, it certainly has others: the risk to a local representative or official committed to sewage sludge utilization of being sued; the risk to food industry actors of being hit by a boycott, more out of fear than due to an actual event; and, finally, the risk of scapegoating faced by a farmer who uses sludge on his fields in an environment where farming practices are often called into question.

The preceding cases highlight the difficulties involved in drawing up different scales of action; neither general, normative measures nor strictly local ones that undermine the scope of action can contribute to a solution. Such cases point to the explosion in Northern societies of a climate where opinion dictates its choices on a purely emotional or self-interested basis, a sort of generalized NIMBY or Not In My Backyard atmosphere, in which local residents are opposed to the roll out or extension of public goods such as industrial sites, waste disposal facilities, communication lines, refugee processing centers, etc. Firstly, NIMBY opposition gives concerned inhabitants a unified and coherent political grouping, clustered around so-called common interests-they form de facto actor coalitions [26]. But this type of action usually evolves quickly to take on different forms, which differ according to what their activists consider to be the key issue worth defending; the result is different pressure groups finally emerging and opposing each other. They have contradictory interests, which is all but normal when considering sustainability transition, which requires synergetic but also antagonistic power dynamics between moderate and radical groups of actors [25]. But instead of developing an inclusive approach by focusing effort on dialog between, and within, all these different groups, public authorities-be they local, regional or national -and project promoters more than often fuel the conflict between the different pressure groups by choosing only a few interlocutors among them whilst ignoring the others. Naturally, when this type of situation occurs, tension grows between the different pressure groups and the situation rapidly becomes chaotic, such that everything is finally disrupted-not just the project itself, but also daily life in the local communities where the project is intended to be put in place. Living conditions worsen rapidly for inhabitants, until a threshold of acceptability is crossed, whereupon public authorities and project promoters can impose just about any project, no matter how dubious, justifying it through exceptional circumstances (sometimes even claiming a state of emergency). Can such an attitude be considered a deliberate strategy on the part of the project stakeholders? To quote Maarten Hajer, "policies are not only designed to solve problems, problems also have to be designed to be able to create policies" 
[27]. Pressure groups usually oppose each other because the narratives that they develop about their environment, and specifically about "quality of life" and "good environment", are different. They oppose each other on the basis of "essentially fragmented and contradictory statements", to quote Hajer again [27]. Thus, environmental conflict occurs primarily over the interpretation of so-called environmental problems. As the different pressure groups realize that they need one another to craft effective political agreements, these conflicts should normally give way to the formulation of a common narrative and objectives [28]. But social power relations have a delicate balance and need time to grow their sources of trust and legitimacy. This evolution never happens when the stakeholders (mainly local authorities and project promoters) act in such a way as to block the process at its conflictual phase.

At this point, the difficulties in drawing up the scales of action as well as the resulting problems, for instance NIMBY movements, highlight the importance of taking imported sustainability into account as an essential component for sustainability policies. David Pearce speaks of imported sustainability when an area guarantees its sustainability by transferring its cost onto other areas; for example by exporting pollution or waste, exporting activities that pollute, or by purchasing natural resources at artificially low prices [29]. This area meets the needs of its population while appearing, on the face of it, to meet the general criteria of sustainability. Internal sustainability is thus achieved through the export of undesired products or impacts, to the detriment of the area's external sustainability [30]. Thus, policies aiming at the realization of sustainable development must be conceived on areas large enough to minimize imported sustainability from outside areas $[2,22]$.

Though less apparent, difficulties also concern temporal scales. Just as inequalities and injustices may arise from one area to another, from one community to another within the same area and from one person to another within the same community, they can be handed down to from one generation to the next. For instance, it seems easy to differentiate between renewable and non-renewable resources, based on man's and society's interactions, destructive or not, with the environmental resources that are accessible to him. However, there is a certain gray area, in that, generally speaking, a renewable resource is a resource that is utilized less rapidly than its natural capacity for regeneration or regrowth. But how are we to estimate this capacity? In many cases, the rate of renewability of a resource is difficult to determine. Forest resources are a good example, with renewability estimates varying greatly depending on whether one is concerned primarily with biodiversity, lumber production, landscape dynamics or soil quality [30]. Furthermore, the notion of "non-renewability" falsely suggests an irreversible process. Irreversibility thus applies only to the scale of human history or that of future generations. It should also be noted that man can produce "non-renewable" resources, for example soils that can take thousands of years to form when left to nature [32].

\section{Resources, Growth and Development: Delicate Balances and Complex Trade-Offs}

Our actions take place within a vast system of biophysical networks. These actions generate a specific discourse, produced by social practices and productive of social practices. This can be considered a "specific ensemble of ideas, concepts, and categorizations that are produced, reproduced, and transformed in a particular set of practices and through which meaning is given to physical and social realities" [27]. In this sense, this discourse structures the environment, or the "nature", of a society. These are both social constructs and, as such, are often exploited by different policy-makers in an attempt to create their own definition of the real world to cover incomplete arguments and biases [33]. So, the environment is embedded in societies. The human being builds a representation of the ecosystems he lives in, and calls it "the environment", he makes of its resources taking (air, water, minerals), inputting (pollution) and altering (housing, transport) [17]. The environment more-orless represents a noisy neighborhood to which we must adapt. Depending on the moment in a societies' history, not all the "items" present in ecosystems are necessarily considered resources. The knowledge we have of our environment changes continually: nature in medieval times was not the same as it is today, if only because the dynamics of the atmosphere and genetics were not well understood. This, of course, raises the crucial issue for sustainable development: what is a resource?

A resource cannot be considered as such by its mere presence. Societies must also possess the knowledge required to make use of it. Coal for example only acquired value as a resource once its combustible properties were discovered and techniques for its use were developed. Prior to this, coal had only negligible value. In addition, inventories of resources change over time. New practices or new relationships to the environment give rise to new resources while others disappear or move toward obsolescence. Besides, expressions such as "repairing nature", "restoring nature", "remediating nature" or even "recreating nature", are very ambiguous. Thus, when some of Spain's political ecologists-for example the Ecologistas en Acción de Tierras de Granadilla [34]speak of "restoring" Mediterranean nature, to which Mediterranean nature are they referring? The climacic deciduous forest that covered Spain ten thousand years ago? The sparse open forest of green oaks, cork-oaks and carob trees of antiquity? Or the garrigas (scrublands) of recent centuries, which in fact 
represent an advanced stage of forest degradation from an ecosystemic point of view? In fact, it is usually the garrigas $[35,36]$. This is not illogical, if we consider that nature is essentially a social construct and there is nothing like a unique ideal biophysical type. But precisely because it is a social construct, the garrigas that the Ecologistas en Acción value so much tell us a lot about their cultural and historical references as well as their vision of Spain today. Garrigas are the recent past of the country so there is nostalgia in such a choice, besides, garrigas are associated in the Spanish collective memory with the civil war-Bunuel's movies and media coverage of the war show scrublands- and the bull silhouette of the Spanish brandy Osborne dominating arid landscapes $[37,38]$. The point is this: were the promoters or the garrigas option conscious of the history they valued indirectly? Probably not.

Besides, what sense does it make to conserve resources for future generations, when we cannot know which resources they will require? Firstly, when asking this question, which generations are we considering? One could argue that everybody thinks spontaneously of his "own" future generations-i.e. those closest to him, both socially and culturally-and not about humanity in its entirety, which remains a rather vague reference. Similarly, at what time horizon does one cease to be interested in the future? On this issue, there is likely a wide divergence of opinion amongst people in different regions of the world; the future is not perceived in the same way when life expectancy is thirty-five as when it is eighty-five, when basic food and health needs are met and when they are not. In addition to the bizarre idea of putting ourselves in the place of future generations to decide on their best interest, sustainable development glosses over the fact that human history, rather than being a continuous process, alternates between relatively stable periods and sudden ruptures that are favorable to development and that cannot be foreseen. Considering that resources vary over time, is our concern for future generations a good enough guide for adapting our productive activities so as to make them less harmful to the environment?

More importantly, the aporia created by trying to determine which resources will be required by absent third parties in an uncertain future results in a theoretical bottleneck when designing sustainability policies. It leads to two definitely divergent views on sustainability-one "weak", and one "strong" [39]. Proponents of "weak" sustainability consider manufactured capital capable of being completely replacing natural capital, with technology answering the environmental challenges arising from the production of goods and services: "the world can, in effect, get along without natural resources, so exhaustion is just an event, not a catastrophe" [40]. Proponents of "strong" sustainability denounce this point of view. They consider manufactured capital incapable of perfectly replacing natural capital, especially some global processes vital to human existence such as the climate or the ozone layer $[41,42]$. In this perspective, it is crucial to limit the qualitative and quantitative degradation of natural capital by diminishing the quantities of material and energy that are extracted from the biosphere and altered [43]. All the more, since there are critical thresholds at which tiny perturbations may irreversibly transform the state of the Earth system once what Lenton calls "tipping elements" cross them. As far as climate change is concerned, monsoon systems, jet streams, coral mega-reefs, tropical rainforests maybe considered "tipping elements" [44].

The Brundtland report is no help in determining the relation between these two sustainabilities. Of course, it points out that the satisfaction of human aspirations should "not endanger the natural systems that support life on Earth: the atmosphere, the waters, the soils, and the living beings...It is part of our moral obligation to other living beings and future generations" [1]. But, simultaneously it promotes a more rapid economic growth in order to overcome poverty, in reference to the "trickle-down theory" which affirms that economic growth is eventually of benefit to everybody and as such reduces poverty [45]. Such a position is ambiguous. It creates confusion on what the substance of sustainable development is, giving room to the divergence between "weak" and "strong" sustainability. Indeed according to Herman Daly, current sustainable development policies seek to correct a mode of development often confused with a mode of growth. As such, the term is oxymoronic as traditional economic growth is clearly unsustainable since it needs more and more resources and produces more and more waste and pollution [46]. Of course, these last years, there have been strenuous attempts to decouple economic growth from material consumption and, for example, to foster recycling channels for material resources [47]. But still, such an approach can be considered based on "weak" sustainability which, according to Rees, turns out to be a "morally bankrupt solution" to poverty [48]. This is not surprising, given that growth has been the mantra of western societies since WWII, stemming from the simplistic vision that increased production by means of industrialization automatically increases mankind's wellbeing. This was true for post-war Europe's devastated economies, at a time when 20th century industrialization was at its peak. It is no longer true in the 21st century, nor for the rest of the world. Yet this belief persists and has taken on a parasitic role in all reflections on sustainability. The Maastricht Treaty goes so far as to use the term "sustainable growth" as a synonym for "sustainable development" [49], so does a recent report from the OECD which drew together green growth and sustainable development policies [50]. 
Sustainable development can also be considered an oxymoron in that the term "sustainable development" itself conceals a fundamental contradiction. Etymologically, the word development implies structural change, be it in embryo development, the process of converting land to a new purpose, the qualitative changes of economic development, or more generally the transition to a new stage in a new situation. But sustainable means the exact opposite-among the many synonyms of the verb "to sustain", we find "to bear", "to continue", "to maintain", "to preserve", "to perpetuate". As such, sustainable development could be understood as "sustained change"-a change that can last forever-which would make it meaningless [51]. Of course, this oxymoron is purely semantic. But it introduces an apparent and original flaw in sustainable development. It induces a recurring question that features prominently in large sectors of academic works on sustainable development, namely, since the words "development" and "sustainable" are so opposed, what is the respective weight of each in the complex notion of sustainable development?

Historically, according to Waas, "in addition to its environmental roots the concept draws on the experience of several decades of development efforts" [9]. Indeed, some authors consider sustainable development to be the successor of traditional development, to which an important environmental dimension was added in 1987, with the WCED report [52]. Thus, human needs, quality of life and increases in everyone's capabilities and wellbeing are the principal issues of sustainable development [53]: As mentioned in Our Common Future: "Poverty...is an evil in itself" [1]. Finally, since sustainable development is a social construct, what it means depends entirely on how the people who define it-whoever they are-see the world they want to live in $[6,54]$. They make choices based on the values they decide to maintain or, more precisely, to sustain. Recently, Bill Hopwood drew up a system of classification and mapping of different trends of people's thought on sustainable development (status quo, reform, transformation) linked to their political and policy frameworks and to their attitudes toward change [4]. But all these trends have a point in common: when under-development threatens the environment and human needs, more development is required; but when development becomes an equal threat, more of the same kind of development is not desired [3].

\section{Combining Spatial and Intergenerational Equity: From Sustainability to Place-Based Sustainabilities}

In a general sense and in the first place, sustainable development is concerned with quality of life, which is about the place of every person in a complex society, about lifestyles and social ties, and not just with material consumption. As such, it seeks to promote a conscious co-evolution between human societies and the ecosystems within which they are embedded. For this reason, sustainable development should be considered a process and not an end state [55]; a process which considers the question of "how decisions are made": It is "not about mobilising resources to realise a pre-determined societal order. Rather, it is about adjusting the structures that regulate societal interactions so that they can encourage positive developmental adaptation" [56]. Therefore, the issue of determining what form of governance is the most effective for actions of sustainable development, is at the heart of sustainability policies. Despite extensive literature on governance for sustainability, "many of its fundamental elements remain unclear in both theory and practice" [57]. Indeed, the term governance, in itself, has very different meanings $[58,59]$. As far as sustainable development is concerned, and in a very general sense, governance is not only about the design and implementation of government policies, but also about the collective process of debate and decision through democratic interactions to ensure that these policies proceed along a sustainable path. It means that the effectiveness of sustainability policies is largely dependent on their acceptability and collective suitability [60]. Thus, the existing social and cultural fabric should not be forgotten [31]. It is, therefore, important to define, on the global scale, what a good environment is for the communities involved, i.e. one in which the improvement of environmental conditions stricto sensu (water quality, air, biodiversity, prudent use of resources, land and energy, etc.) leads to improved living conditions. To do so, it seems logical to put non-market institutions, local communities and individuals able to form selfdetermined user associations together as governance actors-alongside traditional public actors and organizations - to design sustainability policies. This is what Elinor Ostrom demonstrated earlier, when she proved, twenty years ago, that user communities can manage the commons more efficiently than the market or institutional structures, provided that these communities are legally empowered to exclude "free riders" [61,62].

Unfortunately, more than often, the organizations and traditional public actors of sustainable development are inclined to push aside this type of governance-complex and difficult to implement-to replace it with pseudo-governance practices proposing readymade grids and rigid ready-made policies, in contempt of local realities. Such a bias is not confined to local authorities fostering their interests, nor to nations with rigid administrations. In fact there is a strong temptation on the part of international organizations to use normative control measures when dealing with global issues. These organizations produce a profusion of "good practices" furthering the interests of one actor or another. For instance, the World Bank directly 
supported sustainable development projects in poor countries by allocating funds that require the borrowing country to follow directives unilaterally issued by the World Bank [63]. But the priorities of the World Bank were very different from those of the populations. Of the six requirements imposed by the World Bank, two are quite revealing: "encouraging private business development" and "promoting reforms to create a stable macroeconomic environment, to facilitate investment and long-term planning" [64]. On the surface, the intention seems praiseworthy enough, considering that many requesting countries are plagued with widespread patronage. In the recent past, this approach has had many side effects: such requirements were not being suitably adapted to the local conditions and often resulted in disastrous, economic, social and environmental consequences [65]. One participant at a sustainable development conference summed it up thus: "A debate on standards is unavoidable. What sense do standards imposed by the North make, when they care more about micrograms of nitrates in water than about millions of salmonella germs" [66]. This pernicious effect fuels criticism that sustainable development reflects the unilateral insistence of elite Northern countries on concerns like global warming, population growth, species extinction and free market [67]. At the same time, it leads emerging and poor countries to give a veneer of sustainability to their actions, even when unrelated to their real objectives. Sustainability, thus, loses all credibility in the eyes of the local authorities, who write them off as mere whims of the rich nations. Once initiated into the game, they soon get busy maneuvering the imposed sustainable development objectives. Many countries who are unable to manage their resources sustainably will, for example, give much lip service to the themes of poverty and inequalities. They will try so as to legitimize policies which continue to destroy resources or ecosystems. Poverty may even become a resource when it allows access to funds aimed at restoring spatial equity. Obviously, there is need for a sound debate on the normative and practical tensions resulting from the juxtaposition of sustainable development and governance.

On the local scale, these rigid policies also tend to reduce sustainability to its technical dimensions, considering only biophysical, energetic, or ecosystem constraints, without considering any more the social side-effects [68]. For example, with the rising concern on climate change, "exemplary" buildings and devices -all technical solutions-are often favored to the detriment of more holistic approaches, such as active land management and transformation of the urban fabric (differential densification, restructuring urban cores, etc.). To promote "green" buildings, elected officials accept paying extra charges of up to $20 \%$ of the original costs to obtain a Low-Energy label. They are less interested in the urban design, which is more important to creating a real sustainable city but, of course, harder to implement and less profitable as an electoral issue, as in the Clichy-Batignolles urban project, in Paris [69]. Working within the IRCS (International Research Center on Sustainability) at Rheims University on an update of planning practice and theory with regard to sustainability and social justice, I realized that technical issues (such as resource conservation or reduction of greenhouse gases emissions) siphoned money away from other priorities and public and private actors' attention, in accordance with the earlier observations of Elizabeth Burton in similar situations [70]. Since the end of the 1990s, the European Union has financed climate and energy initiatives mainly when sustainability is addressed [71]. Prioritizing this climate topic in local and regional public policies-as in Climate Change Actions Plans-induces very localized eco-technical solutions: energetic autonomy of agglomerations with the development of local renewable energy sources, insulation of buildings, passive houses and so on $[72,73]$. But a zero energy housing development does not necessarily help in creating a sustainable neighborhood. A crucial issue is forgotten here: the fact that sustainable development is also about managing social change.

A larger and larger gap is growing between intergenerational equity (preservation of the resources and protection of the planet for the generations to come, which often goes with more technical approaches) and spatial equity (environmental justice, living conditions). These were not the original intentions of Our Common Future report, which features sustainable development in its ability to cope simultaneously with both spatial equity and intergenerational equity. When the United Nations assigned the writing of a report to the World Commission on Environment and Development (WCED), its mission statement mentioned explicitly that its objectives were how to reduce inequality and poverty without damaging the environment granted to the future generations [1]. Indeed, there is a general equity principle, which we could also call justice or fairness, at the heart of sustainable development [74]. In fact, there are many equities. It is possible to tailor the general principle by addressing different questions [75]. Academic authors usually differentiate between intergenerational equity, spatial equity-which includes intragenerational equity and geographical equity, procedural equity and, finally, interspecific equity [76]. But in fact, the dyad of intergenerational equity and spatial equity is the element that most strongly influences sustainability policies, especially by urging for a clearer distinction between short-term (spatial equity) and long-term (intergenerational equity). Spatial equity refers mainly to the short term and the right for present generations to meet their needs and aspirations, and to have a decent quality of life. It finally has $a$ lot to do with the term 
"development" in "sustainable development" and with social justice. Intergenerational equity, on its side, refers mainly to the long term, to the right for future generations to live on a healthy planet which means to keep our economic activities within the environmental limits of the Earth. Fundamentally, it relates to the term "sustainable" in "sustainable development". Officially, of course, sustainable development is an integrative notion that should harmoniously unify development objectives with environmental objectives [77]. But, it is evident that these two equities are antagonistic notions, which cut across the antagonism between weak and strong sustainability seen above in this article: trade-offs are often necessary, which, currently, usually favor intergenerational equity, suggesting sacrifices among the general sustainability objectives. Besides, the environment is only one of the 3 "pillars" of sustainable development together with social and economic aspects. The idea of three separate and connecting pillars, leads to the erroneous impression that each one is, in part, independent of the others. But humanity is completely dependent on its environment, and the environment is completely transformed by the economy and the societies existing within it, and the resources used by the economy all come from the environment or the societies themselves, and so on [77]. Therefore the perception of the three "pillars" is certainly the least appropriate in depicting sustainable development; curiously it is the most popular [78].

\section{Conclusions}

There are numerous ongoing debates about sustainable development. Though the theoretical corpus on sustainable development is already considerable, it is constantly evolving and presents many internal contradictions. This is due, in large part, to its wide dissemination through various domains and sectors: political, administrative, activist, corporate, etc. As a consequence, different authors use the same words to describe sometimes very conflicting perspectives, goals and methods about how to foster transition to sustainability. They introduce their own cultural, scientific, political and ideological backgrounds into the debates. The success of sustainability policies is often compromised by poor coordination between different decision levels (states, regions, cities, local

\section{References and Notes}

1. WCED. Our Common Future. Oxford, UK: Oxford University Press; 1987.

2. Elliot J. An Introduction to Sustainable Development. London, UK: Routledge; 2006.

3. Robinson J. Squaring the Circle? Some Thoughts on the Idea of Sustainable Development. Ecological Economics. 2003;48:369-384. governments), each one with its own priorities and its own strategic position. In this paper, it has been shown that the well-known adage that sustainability should be "thought globally and acted locally" is very difficult to implement. Every person and community living has various relationships based on various territorial scales. Implementing sustainable development leads to permanent dilemmas, which generate radically different policies depending on the balance between equities.

So, there is no such thing as a single unified conception of sustainable development, and a key factor is explaining why it is so difficult to implement effective sustainability policies: around the world, existing political, cultural and economic contexts, as well as existing environmental policies, interfere with sustainability initiatives to create very complex situations [79]. Finally, since the multiple antagonistic views on sustainability cannot be reconciled, no single approach should be seen as correct. As a matter of consequence, there is no such thing as sustainability, there are only sustainabilities. Universal solutions do not exist and cannot meet the specificities of local contexts, anyway. Thus, traditional singular, top-down, global-to-local approaches to the sustainable development model should be substituted by multiple sustainabilities.

The hotchpotch of undifferentiated sustainability suddenly makes sense when you consider each initiative from a local perspective. Thus, local sustainability policies, rather than blindly observing global injunctions and rigid rules, should adapt themselves to local interests, local cultures and preceding codes or policies. Eventually, these local issues will often antagonize, as mentioned in this paper with cross-border pollution or imported sustainability conflicts. In reality, instead of focusing on objectives to be achieved, sustainability policies do make much more sense if considered as a process where different and even divergent views can be expressed and confronted. This position-an open one -acknowledges sustainable development as a political issue and gives insight into how to successfully foster transition to sustainability, it calls for a comprehensive approach that considers all human factors, such as collective representations, perceptions and power relationships.

4. Hopwood B, Mellor M, O'Brien G. Sustainable Development: Mapping Different Approaches. Sustainable Development. 2005;13:38-52.

5. Leiserowitz A, Kates R, Parris T. Sustainability Values, Attitudes, and Behaviors: A Review of Multinational and Global Trends. Annual Review of Environment and Resources. 2006;31:413-444.

6. Christen M, Schmidt S. A Formal Framework for Conceptions of Sustainability-A Theoretical Con- 
tribution to the Discourse in Sustainable Development. Sustainable Development. 2012;20(6):400-410.

7. Lozano R. Envisioning Sustainability Threedimensionally. Journal of Cleaner Production. 2008; 16:1838-1846.

8. Dresner S. The Principles of Sustainability. 2nd ed. London, UK: Earthscan; 2008.

9. Waas T, Hugé J, Verbruggen A, Wright T. Sustainable Development: A Bird's Eye View. Sustainability. 2011;3(10):1637-1661.

10. Gibson R. Specification of Sustainability-Based Environmental Assessment Decision Criteria and Implications for Determining "Significance" in Environmental Assessment. Research and Development Monograph Series. Quebec, Canada: Canadian Environmental Assessment Agency; 2000.

11. Mirovitskaya N, Ascher W. Guide to Sustainable Development and Environmental Policy. Durham NC, USA: Duke University Press; 2002.

12. Mäler KG. International Environmental Problems. Oxford Review of Economic Policy. 1990; 6(1):80-108.

13. Levshina SI, Efimov NN, Bazarkin VN. Assessment of the Amur River Ecosystem Pollution with Benzene and Its Derivatives Caused by an Accident at the Chemical Plant in Jilin City, China. Bulletin of Environmental Contamination and Toxicology. 2009;83(6):776-779.

14. Kirschner LA, Grandy EB. The Songhua River Spill: China's Pollution Crisis. Natural Resources and Environment. 2006;20(4):66-68.

15. Nagase $Y$, Silva ECD. Acid Rain in China and Japan: A Game-theoretic Analysis. Regional Science and Urban Economics. 2007;37(1):100-120.

16. Saitoh K, Sera K, Shirai T. Characterization of Atmospheric Aerosol Particles in a Mountainous Region in Northern Japan. Atmospheric Research. 2008;89(4):324-329.

17. Mancebo F. Le développement durable, second edition. Paris, France: Collection U, Armand Colin; 2010.

18. Repertoire De Jurisprudence I Arret Mine De Potasse D'Alsace. Available from: http://www.lexinter. net/JPTXT/arret_mine_de_potasse_d'alsace.htm (accessed on 28 May 2013).

19. Dresner S. The Principles of Sustainability. London, UK: Earthscan; 2002.

20. Monday JL. Building Back Better: Creating a Sustainable Community After Disaster. Natural Hazards Informer. 2002;3(February). Available from: http://www.colorado.edu/hazards/publications/inform er/infrmr3/ (accessed on 28 May 2013).

21. Cornell S. On the System Properties of the Planetary Boundaries. Ecology and Society. 2012; 17(1):r2. Available from: http://www.ecologyand society.org/vol17/iss1/resp2 (accessed on 28 May 2013).

22. Rockström J, Steffen $W$, Noone K, Persson A, Chapin FS, Lambin E, Lenton TM, Scheffer M, Folke C,
Schellnhuber J, Nykvist B, De Wit CA, Hugues T, Van Der Leeuw S, Rodhe H, Sörlin S, Snyder PK, Costanza R, Svedin U, Falkenmark M, Karlberg L, Corell RW, Fabry VJ, Hansen J, Walker B, Liverman D, Richardson $\mathrm{K}$, Crutzen P, Foley J. Planetary Boundaries: Exploring the Safe Operating Space for Humanity. Ecology and Society. 2009;14(2):32. Available from: http://www. ecologyandsociety.org/vol14/iss2/art32 (accessed on 28 May 2012).

23. Butler RA, Pin Koh L, Ghazoui J. REDD in the red: Palm oil could undermine carbon payment schemes. Conservation Letters. 2009;2(2):68-73.

24. Mancebo F. Quels référentiels pour un "aménagement durable"? L'Information Géographique. 2007;3:29-47.

25. Avelino F. Power in Transition. Empowering Discourses on Sustainability Transitions. PhD thesis. Rotterdam, The Netherlands: Faculty of Social Science, Erasmus University; 2011.

26. Sabatier PA. Knowledge, Policy-oriented Learning, and Policy Change. Knowledge: Creation, Diffusion, Utilization. 1987;8(4):649-662.

27. Hajer M. The Politics of Environmental Discourse: Ecological Modernization and the Policy Process. Oxford, UK: Oxford University Press; 1995.

28. Hajer $M$, Wagenaar $H$. Deliberative Policy Analysis: Understanding governance in the network society. Cambridge, UK: Cambridge University Press; 2003.

29. Pearce D, Markandya A, Barbier EB. Blueprint for a Green Economy. London, UK: Earthscan Publication; 1989.

30. Hoekstra A, Mekonnen M. The Water Footprint of Humanity. Proceedings of the National Academy of Science of the USA. 2012;109(9):3232-3237.

31. Costanza R, Low BS, Ostrom E, Wilson J. Institutions, Ecosystems, and Sustainability. New York, NY, USA: Lewis Publishers; 2001.

32. Soule JD, Piper JK. Farming in Nature's Image, An Ecological Approach to Agriculture. Chicago, IL, USA: Island Press; 1992.

33. Hajer M, Versteeg W. A Decade of Discourse Analysis of Environmental Politics: Achievements, Challenges, Perspectives. Journal of Environmental Policy and Planning. 2005;7(3):175-184.

34. Ecologistas en Acción. Available from: http:// www.ecologistasenaccion.org/article12948.html (accessed on 28 May 2013).

35. Maroto Iglesias M. Política ambiental y valorización del paisaje: la Red de Espacios Naturales Protegidos de Castilla y León. PhD thesis. Valladolid, Spain: Escuela Universitaria de Magisterio, Universidad de Valladolid; 2012.

36. Martinez J, Esteve MA. Desertificación en España: Una perspectiva crítica. El ecologista; 2006. Available from: http://www.rebelion.org/noticias/ 2006/6/33768.pdf (accessed on 28 May 2013).

37. De Solis PM. El "Toro de Osborne" y la identidad cultural. Reflexiones desde la sociologia del 
arte. Des taureaux et des hommes. Duviols JP, Molinié-Bertrand A, Guillaume-Alonso A, editors. Paris, France: Presse Paris Sorbonne; 1999.

38. Herrera Navarro J. Estudios Sobre Las Hurdes de Buñuel (Evidencia Fílmica, Estética y Recepción). Coleccion Iluminaciones. Madrid, Spain: Renacimiento; 2006.

39. Haughton G, Hunter C. Sustainable Cities. London, UK: Kingsley; 1994.

40. Solow R. The Economics of Resources or the Resources of Economics. American Economics Review. 1974;64:1-14.

41. Daly $H$. Reconciling Internal and External Policies for Sustainable Development. In: Dragun AK, Jacobson KM, editors. Sustainability and Global Economic Policy. Cheltenham, UK: Elgar; 1998.

42. Roseland M. Towards Sustainable Communities: Resources for Citizens and their Governments. Gabriola Island, Canada: New Society; 1998.

43. Von Weizsäcker EU, Lovins AB, Lovins LH. Factor Four: Doubling Wealth, Halving Resource Use. London, UK: Earthscan; 1997.

44. Lenton TM, Held H, Kriegler E, Hall JW, Lucht W, Rahmstorf S, Schellnhuber HJ. Tipping Elements in the Earth's Climate System. Proceedings of the National Academy of Science of the USA. 2008; 105(6): 1786-1793.

45. Dollar D, Kraay A. Growth is Good for the Poor. Washington, DC, USA: World Bank; 2000.

46. Daly H. Sustainable Growth: An Impossibility Theorem. In: Daly $\mathrm{H}$, Townsend $\mathrm{K}$, editors. Valuing the Earth: Economics, Ecology Ethics. Cambridge, MA, USA: MIT Press; 1993.

47. Fischer-Kowalski $M$, Von Weizsäcker UE, Ren Y, Moriguchi $Y$, Crane W, Krausmann F, Eisenmenger N, Giljum S, Hennicke P, Kemp R, Romero Lankao P, Siriban Manalang AB. Decoupling Natural Resource Use and Environmental Impacts from Economic growth. Geneva, Switzerland: UNEP; 2011.

48. Rees W. Understanding Sustainable Development. Hamm B, Muttagi P, editors. Sustainable Development and the Future of Cities. London, UK: Intermediate Technology; 1998.

49. Wilkinson D. Maastricht and the Environment: The Implication for the EC's Environment Policy of the Treaty on European Union. Journal of Environmental Law. 1992;4(2):221-239.

50. OECD. Incorporating Green Growth and Sustainable Development Policies into Structural Reform Agendas. Report. OECD Publishing; 2012.

51. Lélé S. Sustainable Development: A Critical Review. World Development Journal. 1991;19(6):607621.

52. Zaccaï E. Le développement durable: Dynamique et constitution d'un projet. Brussels, Belgium: Peter Lang; 2002.

53. Langhelle $\mathrm{O}$. Why Ecological Modernization and Sustainable Development Should Not Be
Conflated. Journal of Environmental Policy and Planning. 2000;2(4):303-322.

54. Lafferty W, Meadowcroft J. Implementing Sustainable Development. Strategies and Initiatives in High Consumption Societies. London, UK: Oxford University Press; 2000.

55. Meadowcroft J. Planning for Sustainable Development: Insights from the Literatures of Political Science. European Journal of Political Research. 1997;31(4):427-454.

56. Meadowcroft J, Farrell KN, Spangenberg J. Developing a Framework for Sustainability Governance in the European Union. International Journal of Sustainable Development. 2005;8(1/2):3-11.

57. Biermann F, Pattberg P. Global Environmental Governance Reconsidered. Cambridge, MA, USA: MIT Press; 2012.

58. Pierre J. Debating Governance: Authority, Steering and Democracy. London, UK: Oxford University Press; 2000.

59. Kooiman J. Governing as Governance. London, UK: Sage; 2003.

60. Theys J. Développement durable, villes et territoires, innover et décloisonner pour anticiper les ruptures. Notes de prospective et de veille scientifique. Paris, France: Ministère de l'Équipement; 2000.

61. Ostrom E. A Behavioral Approach to the Rational Choice Theory of Collective Action. American Political Science Review. 1998;92(1):1-22.

62. Ostrom E, Schroeder L, Wynne S. Institutional Incentives and Sustainable Development: Infrastructure Policies in Perspective. Boulder, $\mathrm{CO}$, USA: Westview Press; 1993.

63. Mehta L. Commentary: The World Bank and Its Emerging Knowledge Empire. Human Organization. 2001;60(2):189-196.

64. World Bank. A Guide to the World Bank. 3rd ed. Washington, DC, USA: World Bank; 2011. Available from: https:// openknowledge.worldbank. org/handle/10986/2342 (accessed on 28 May 2013).

65. Ellerman D. Helping People Help Themselves: From the World Bank to an Alternative Philosophy of Development Assistance. Series Evolving Values for a Capitalist World. Ann Arbor, MI, USA: The University of Michigan Press; 2006.

66. Groupe de Prospective du Sénat. L'eau: Un défi pour l'humanité, au cœur des stratégies pour un développement durable. France, Paris: Sénat; 2003.

67. Doyle T. Sustainable Development and Agenda 21: The Secular Bible of Global Free Markets. Third World Quarterly. 1998;19(4):771-786.

68. Mancebo F. La ville durable est-elle soluble dans le changement climatique? Environnement Urbain-Urban Environment. 2011;5:a1-a9.

69. Barbry L. La participation de la société civile à des projets d'aménagement urbain: une démarche enjeu d'un développement durable? Les éco-quartiers sont-ils le lieu de prédilection de la participation? 
Paris, France: Ecole d'architecture de la Villette; 2011.

70. Burton E. The Compact City and Social Justice. Housing, Environment and sustainability Conference. York, UK: Proceedings of the Housing Studies Association Spring Conference; 2001.

71. European Commission. A Sustainable Europe for a Better World: A European Union Strategy for Sustainable Development (Commission's proposal to the Gothenburg European Council). 2001. Available from: http://eur-lex.europa.eu/LexUriServ/LexUriServ.do? uri=CELEX:52001DC0264:EN:HTML (accessed on 28 May 2013).

72. Droege P. Urban Energy Transition: From Fossil Fuel to Renewable Power. Amsterdam, The Netherlands: Elsevier; 2008.

73. Criqui P, Russ P, Deybe D. Impacts of Multigas Strategies for Greenhouse Gas Emission Abatement: Insights from a Partial Equilibrium Model. Energy Journal. 2006;29(Special Issue 3):251-273.

74. Cairns J. Equity, Fairness, and the Development of a Sustainability Ethos. Ethics in Science and Environmental Politics. 2001:1-7.

75. Gibson R, Hassan S, Holtz S, Tansey J, Whitelaw G. Sustainability Assessment-Criteria and Processes. London, UK: Earthscan; 2005.

76. Haughton G. Environmental Justice and the Sustainable City. Journal of Planning Education and Research. 1999;18(3):233-243.

77. Giddings B, Hopwood B, O'Brien G. Environment, Economy and Society: Fitting them together into Sustainable Development. Sustainable Development. 2002;10(4):187-196.

78. Dawe N, Ryan K. The Faulty Three-leggedstool Model of Sustainable Development. Conservation Biology. 2003; 17(5):1458-1460.

79. Sterman JD. Sustaining Sustainability: Creating a Systems Science in a Fragmented Academy and Polarized World. In: Weinstein MP, Turner ET, editors. Sustainability Science: The Emerging Paradigm and the Urban Environment. New York, NY, USA: Springer; 2012.

80. Papy F, Houot $S$. Le bouclage des flux organiques entre ville et campagne. In: Papy $F$, Mathieu N, Ferault C. editors. Nouveaux rapports à la nature dans les campagnes. Collection Indisciplines:
71-83. Paris, France: Editions Quae; 2012.

81. Agence de l'Environnement et de la Maîtrise de l'Energie. Available from: http://www.ademe. $\mathrm{fr} /$ partenaires/boues (assessed on 28 May 2013).

82. OJEC, July $41986, n^{\circ} \mathrm{L} 181$.

83. Houot S. Recyclage des déchets sur les sols: Valeur agronomique et impacts environnementaux. In: Girard MC, Walter C, Rémy JC, Berthelin J, Morel $\mathrm{JL}$, editors. Sols et Environnement. Paris, France: Dunod; 2011. pp. 637-660.

84. Borraz O, D'Arcimoles M, Salomon D. Un risque socialement inacceptable? La crispation autour de I'utilisation en agriculture des boues de station d'épuration. Rapport programme risques collectifs et situation de crise. Grenoble, France: ADEME; 2000.

85. BSE is a fatal neurodegenerative disease in bovine cattle that causes a spongy degeneration in the brain and spinal cord. It has a long incubation period (up to 8 years) and usually affects adults. The disease was transmitted to human beings by eating contaminated animals. It was then known as variant Creutzfeldt-Jakob disease. BSE was caused by cattle being fed with the remains of other cattle in the form of meat and bone meal (MBM).

86. Dudkowski A. L'épandage agricole des boues de stations d'épuration d'eaux usées urbaines. Le Courrier de l'environnement. Paris, France: INRA. 2000. p. 40.

87. Chrifi H. Quel apport du principe de précaution à l'évaluation des modèles de prise en charge instrumentale des problèmes environnementaux? Le cas de la gestion des boues de stations d'épuration. L'évaluation environnementale: vers une harmonisation internationale? VIIe Colloque International des spécialistes francophones en évaluation d'impacts, Liege, France; 2002.

88. Cardona A, Lamine C, Hochereau F. Mobilisations et animations autour des réductions d'intrants : Stratégies d'intéressement des agriculteurs dans trois territoires franciliens. Revue d'Etudes en Agriculture et Environnement. 2012;93(1):49-70.

89. Salomon D. Champlan en Essonne, village pilote: Les inquiétudes sanitaires d'un village d'Ile-deFrance soumis à un cumul d'infrastructures et de nuisances. Rapport INVS; 2010. 


\section{Appendix: Land Application of Sewage Sludge in France: Conflicts and Mistrust}

In the 1970s, sewage sludge utilization in agriculture was a confidential and mutually beneficial arrangement between sewage treatment plants and farmers. Many authors stress the double advantage of transforming urban waste into an agricultural resource for nearby rural communities [80]. This practice gradually came to be organized under the auspices of the French Agency for Environment and Energy Management (ADEME) and the Permanent Assembly of the Chamber of Agriculture (APCA) as a sustainability policy initiative [81]. In 1986, the Council of Europe issued a directive to clarify the status of sewage sludge-one difficulty stemmed from its dual status as both waste and fertilizer-and the requirements for its utilization, as well as to provide health and environmental guidelines [82]. The French Ministry of the Environment transposed it into a national decree in 1988.

In the 1990s, sewage sludge production increased steadily as a result of both the incentive of the decree and stricter regulations on the treatment of waste water, sewage sludge use on agricultural lands increased sharply, giving rise to a high incidence of odor nuisances [83]. In the Paris regions, nonfarmering neighbors began to protest: opposition movements appeared that antagonized local periurban communities [24]. Some land owners threatened to stop renting their properties for farming purposes, claiming that sewage sludge utilization would negatively impact their property value [84].

At the same time, certain sectors of the food industry, in particular food distributors, began taking positions to limit, or even forbid sewage sludge utilization. Indeed, at the beginning of the 1990s, the BSE (Bovine Spongiform Encephalopathy) crisis, in Europe also named the "mad cow" crisis, surged [86]. Linked to the incorporation of meat and bone meal in cattle feed, it lent itself to the idea that incorporating any non-traditional components into the food chain presents a health risk [87]. Confusion was such that there were even rumors that sewage sludge was utilized in animal feed, instead of animal meal from meat rendering facilities. Finally, the financial benefits of sewage sludge utilization, instead of constituting a positive argument, further increased distrust among the public, who perceive health matters and economic matters as systematically opposed [88].

Placed under considerable pressure, some farmers then began to refuse sewage sludge. In the Paris region, many authors addressed these conflicts between different local actors (farmers, non-farmers inhabitants, companies, local authorities, etc.) concerning the utilization of sewage sludge on fields, but no practical negociation tool to cope with this problem emerged [89].

Though, alternative disposal means for sewage sludge were rarely discussed by the opponents of agricultural utilization, who tended to frame the debate in simplistic "city vs. country" terms. These opponents, principally urban dwellers, tended not to see themselves as immediately concerned by the waste elimination problem. Sooner or later though they will have to come to terms with the fact that they generate the bulk of the waste and that if nothing is done they might one day "find themselves submerged in it" as expressed by an inhabitant of the village of Champlan, near Paris, during a study addressing the acceptability of this "nuisance" [89]. 